\title{
Stakeholder Engagement: A Conceptual Framework and Initial Validation to Foster Sustainability Development in a Maritime Cluster
}

\author{
Oluyomi Abayomi Osobajo ${ }^{1 *}$, Yannis Koliousis ${ }^{2}$, Heather McLaughlin ${ }^{3}$
}

\author{
${ }^{1}$ Aberdeen Business School Robert Gordon University Garthdee Road Aberdeen AB10 7QE, UK \\ ${ }^{2}$ School of Strategy \& Leadership Coventry Business School Coventry University William Morris Building Gosford Street COVENTRY CV1 5D, UK \\ ${ }^{3}$ Faculty of Business and Law De Montfort University The Gateway Leicester LE1 9BH, UK \\ *Corresponding Author: o.osobajo@rgu.ac.uk
}

Citation: Osobajo, O. A., Koliousis, Y. and McLaughlin, H. (2021). Stakeholder Engagement: A Conceptual Framework and Initial Validation to Foster Sustainability Development in a Maritime Cluster. European Journal of Sustainable Development Research, 5(1), em0149. https://doi.org/10.21601/ejosdr/9664

\section{ARTICLE INFO}

Received: 13 Aug. 2020

Accepted: 8 Oct. 2020

\begin{abstract}
Sustainability development, as a concept, is becoming an important topic for discussion within the maritime industry due to its environmental impact and intensification of the compliance framework. Achieving sustainable development will require involvement from the industry diverse stakeholders. Yet the ongoing discussions and research studies on promoting sustainability within the maritime industry gave no attention to engaging the various stakeholders existing and/or operating within the industrial or professional cluster, whose absence from the decision-making processes may fail to address sustainability issues within the industry. This study argues in support of actively engaging the maritime industry diverse stakeholders to foster the implementation of sustainable development. Based on desk research and validation from subject experts, we propose a conceptual engagement framework that may be adopted by shipping entities to correctly identify and engage the industry key stakeholders towards promoting sustainable development.
\end{abstract}

Keywords: stakeholder, stakeholder engagement, sustainability development, maritime clusters

\section{INTRODUCTION}

The maritime industry is a significant source of economic growth, innovation and value-creating business sector. The industry's role in providing intermediate goods and services for other sectors (Kwak et al., 2005), source of employment and economic growth (Doloreux and Melançon, 2008), and providing global transportation (Kacmaz et al., 2016) are pivotal. These views are consistent with Chen et al. (2016) assertion that the maritime industry is essential to a nation's economic growth. However, scholars such as Dinwoodie et al. (2012) argued further that unsustainable maritime activities and development could result in risks of catastrophic environmental damage. In support of this argument, Potter (2017) stated that the industry comes at a cost to the environment despite its numerous contributions. As a result, the International Maritime Organization (IMO) continue to campaign and raise awareness of the United Nations' Sustainable Development Goals with the 2020 World Maritime Theme of "Sustainable shipping for a sustainable planet" (IMO, 2020). IMO focus was on compliance framework on sustainable development, which considers the three dimensions of sustainable development, i.e. economic, social and environmental for the industry simultaneously. These views suggest that both scholars and international institutions are demanding for sustainable development in the maritime sector.

Concern for economic, social and environmental issues in the maritime industry came into view before the emergence of sustainable development due to the negative environmental and societal impacts of the industry. Johnson et al. (2013) asserted that the industry many challenges such as lack of knowledge and resources, lack of communication, and poor project management has been limiting factors to the attainment of environmentally-sustainable practices in the industry. With the increase of environmental concerns with regards to the activities of the maritime industry, IMO developed and formulated innovative policies and targets for the industry to respond to the needs of countries at the national, regional and global levels. Yet sustainable development remains a growing concern for the maritime industry. Lee and Lam (2012) asserted that organisations operating within the industry must abide by environmental policies, regulations and promote awareness to support 
sustainable development. This suggests the need for stakeholders in the industry to mobilise and share knowledge, technology, expertise and other resources to promote sustainable development within the maritime industry. As non-engagement of the industry, diverse stakeholders or professional clusters could result in threats in a broader context.

Dinwoodie et al. (2012) stated that an accessible framework, which increases stakeholder engagement is imperative to support the planning of sustainable maritime operations and encourage engagement with sustainability agendas. This suggests that a participatory decision-making process among stakeholders is essential for the successful formulation and implementation of sustainable strategies for the industry. However, Maguire et al. (2012) observed that "there is limited literature focusing on the direct involvement of stakeholders in the industrial process, including a lack of indepth stakeholder analysis and methodology on how/when to best incorporate them". It is, therefore, imperative to encourage the involvement of the industry diverse stakeholders in strategising sustainability initiatives. As actively attracting the engagement of these stakeholders will foster the implementation of sustainable development within the industry.

This paper focuses on developing a conceptual framework to correctly identify the key stakeholders within a maritime cluster that will promote active stakeholder engagement and thus encouraging sustainable development by simplifying and reframing Reed's (2008) robust stakeholder engagement framework. Hence, the paper contributes to both practice and theory in two different ways. First, the study develops a framework to facilitate stakeholder engagement in fostering sustainable development. Second, the study adds to the understanding of stakeholder engagement within the maritime industry.

\section{LITERATURE REVIEW}

\section{What makes Maritime Sustainable?}

The absence of a common understanding among scholars and researchers concerning sustainable development as resulted in the concept being characterised as ambiguous, vague, contradictory and undefined. Its incorrect use as a synonym of environmental and/or ecological create further complications. While the expression of diverse opposing views by scholars and researchers about the concept definition is not causeless and/or meaningless, Engel (1990: 10) defined sustainable development as "the kind of human activity that nourishes and perpetuates the historical fulfilment of the whole community of life on earth". Gladwin et al. (1995: 878) added that sustainable development as a concept is "a process of achieving human development in an inclusive, connected, equitable, prudent, and secure manner". Sustainable development promotes both local and global efforts in which basic human needs are met without destroying or irrevocably degrading the natural systems on which we all depend. Arguably, these views suggest that environmental protection, economic growth and social equality are important aspects while explaining sustainable development.
Building on the previous paragraph, one could argue that the maritime industry is said to be sustainable when it delivers economic development, responds to social development and meets environmental challenges. Svensson's (2012) concur with this argument by stating that economic development, social development and environmental protection are the three pillars of sustainable development in the maritime industry as defined below:

* Economic development: focus on the economic growth of the industry without having adverse effects on social and environmental development.

* Social development: Focus on ensuring the wellbeing of people who are directly or indirectly in contact with the industry.

* Environmental protection: Focus on preserving the environment in which the maritime activities and/or operations are carried out.

\section{Delineation of the Various Classes of Maritime Stakeholders}

Considering the maritime industry significant contribution to the economic and social development of the world at large, it becomes imperative to assess the various players within the industry. Viederyte (2013) in support of this argument, stated that identifying the maritime stakeholders' avails organisations the opportunity to optimise efficiency, promote innovation and increases the level of business formations. The industry focuses on anything as it relates to ships, sea, ocean and other related activities. Figure 1 presents an overview of the main maritime industry stakeholders. This list is in no way exhaustive as the process of identifying stakeholders is "a dynamic activity that flows with the tide of events and issues within the business environment" (Amaeshi and Crane, 2006: 252). The purple circles denote the stakeholders who are considered internal to the maritime industry, while the other stated stakeholders are perceived external to the industry. These stakeholders are termed internal because they have a direct impact and/or influence on the industry primary activities, while external stakeholders are entities not within a business itself but who care about or are affected by its performance (Denktas-Sakar and Karatas-Cetin, 2012). It is imperative to state that shipping is a core aspect of the maritime industry (Arslan et al., 2016).

The different maritime stakeholders and stakeholder groups identified in Figure $\mathbf{1}$ have different interests and concerns (Ammar et al., 2016). This often results in the difficulty experienced while trying to balance their different needs. Table 1 presents the different interests and concerns of these stakeholders.

\section{Sustainable Stakeholder Engagement in Maritime Clusters}

Maritime clusters as a concept have been defined in a different context which could be attributed to its distinct popularity. For example, de Langen (2002: 2130) referred to the maritime cluster as "a set of activities strongly related to building and operating ships, such as port services, maritime services and ship suppliers". This is consistent with Benito et al. (2003: 203) assertion that maritime clusters consist of "shipyards, ship equipment manufacturers, and ship 


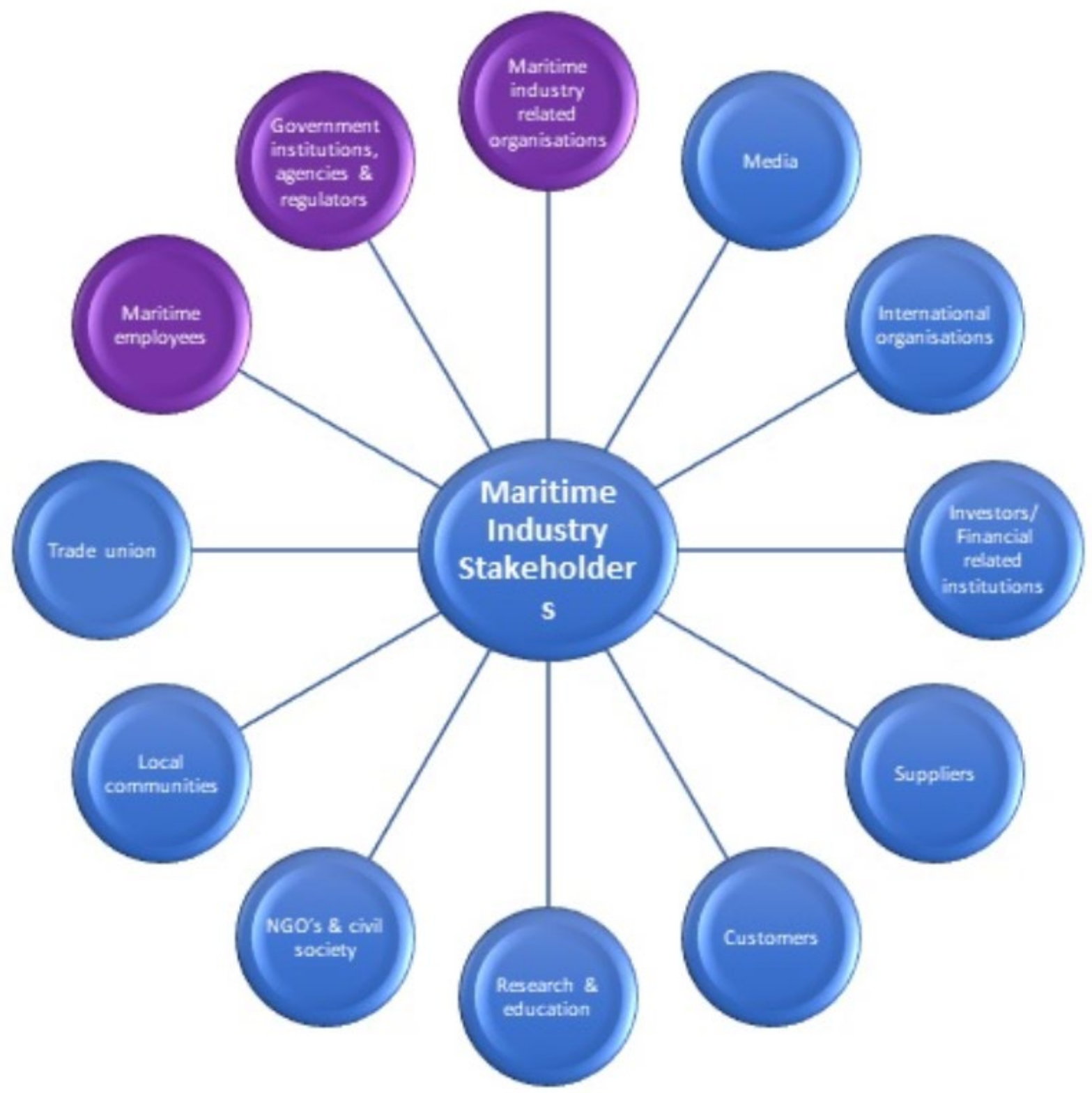

Figure 1. Maritime industry stakeholders (Authors generated)

consultants, and a plethora of other companies and institutions with maritime oriented activities". These views suggest clusters constitute of firms, which are interconnected and complement each other. Koliousis et al. (2018) argued that each type of member within a cluster has its role in solidifying and sustaining the health of the collection of entities. Also, Doloreux and Shearmur (2009: 522) referred to maritime clusters as a "concentration of firms in a domain (maritime sectors), research and education organisations which are active in a related field and the presence of public support mechanisms operated by the government and regional stakeholders, through which actors share a common vision of growth and innovation strategies". This view perceives clusters to be a geographical collection of maritime industries within a locality and the presence of a chain of institutions and firms that contribute to the industry development. Pagano et al. (2016: 170) added that maritime clusters involve "a set of maritime activities that have direct (canal), indirect (bunkering and shipping agencies, shipping, ship chandlers, ship repair and maintenance, launch and pilotage services, dredging), induced (free trade zone, tourism, ports, container repair) and parallel (banking and insurance) effects on the maritime economy”. Hence, Pinto et al. (2015) argued and concluded that maritime clusters connote different meanings subject to the sectors in which it is being explored.

Maritime clusters can, therefore, be a geographical concentration of interlinked and/or interconnected firms, service providers, suppliers, associated institutions and firms operating in related industries. Even though Maritime clusters bring together different businesses and people; the literature has given no attention to how effective engagement can be achieved. Yet the evolvement of the maritime clusters over time concerning the actors and service providers' composition within the maritime industry supports the need for stakeholder engagement in sustainable development. Rotheroe et al. (2003) in support of this argument, asserted that sustainable development could only be given real meaning and achieved through a multi-stakeholder involvement. Engaging with parties who can enforce their expectations on the organisation is imperative as their needs 
Table 1. List of stakeholders in the maritime industry (Summarised from the literature)

\begin{tabular}{|c|c|c|}
\hline Stakeholder Group & Example(s) & Role(s) \\
\hline \multicolumn{3}{|l|}{ Internal } \\
\hline $\begin{array}{l}\text { Maritime industry related } \\
\text { entities that operate } \\
\text { within the industry }\end{array}$ & $\begin{array}{l}\text { Ship owners' } \\
\text { Ship operators } \\
\text { Stevedores \& terminals } \\
\text { Support services } \\
\text { Port operators }\end{array}$ & $\begin{array}{l}\text { Provide cargo transport services } \\
\text { Provide infrastructures and facilities required to receive ships } \\
\text { Responsible for loading and unloading ships and storing cargo } \\
\text { Offer their services to support the industry. Include ship brokers, shipping } \\
\text { agencies, inspection and standard-compliance services, dredging, towing, pilot } \\
\text { services and equipment repair. }\end{array}$ \\
\hline $\begin{array}{l}\text { Government institutions, } \\
\text { agencies \& regulators }\end{array}$ & $\begin{array}{l}\text { Port authorities } \\
\text { Maritime Regulator } \\
\text { Transnational Associations and } \\
\text { Accords }\end{array}$ & At national and international level ensures ship registration and control \\
\hline Maritime employees & $\begin{array}{l}\text { Individual Employees } \\
\text { Labour Associations at the entity } \\
\text { level } \\
\text { Regional Associations }\end{array}$ & $\begin{array}{l}\text { They contribute to the successful functioning, growth and development of the } \\
\text { industry by offering their expertise. }\end{array}$ \\
\hline \multicolumn{3}{|l|}{ External } \\
\hline Trade union & Associations at the industry level & Make attempt at regulating the maritime industry externally. \\
\hline Local communities & $\begin{array}{l}\text { Local councils / boroughs } \\
\text { Local / Regional Authorities } \\
\end{array}$ & Attempt to improve sustainability, local / regional growth and quality of life \\
\hline NGO's \& civil society & Environmental pressure groups & $\begin{array}{l}\text { Establish and maintain standards for the operation of industry. Also, they } \\
\text { sometimes provide certification for ongoing services, confirming that the } \\
\text { activities and operations of the industry complies with the required standards. }\end{array}$ \\
\hline $\begin{array}{l}\text { Research \& education } \\
\text { community }\end{array}$ & $\begin{array}{l}\text { Training institutions } \\
\text { CPD providers } \\
\text { Tertiary education entities }\end{array}$ & $\begin{array}{l}\text { Implement studies/research activities for developmental purposes. } \\
\text { Train employees. Train students and produce future employees. }\end{array}$ \\
\hline Customers & $\begin{array}{l}\text { Retailers } \\
\text { Manufacturers } \\
\text { Cargo owners }\end{array}$ & $\begin{array}{l}\text { Support the industry continuity and survival by helping the organizations } \\
\text { operating within the industry meets their goals through the purchase of goods } \\
\text { and services they offer. }\end{array}$ \\
\hline Suppliers & Marine services & $\begin{array}{l}\text { Provides products and services required by the organisations operating within } \\
\text { the industry for function efficiently. }\end{array}$ \\
\hline $\begin{array}{l}\text { Investors/Financial related } \\
\text { institutions }\end{array}$ & $\begin{array}{l}\text { Banks } \\
\text { Insurance companies } \\
\text { Stock exchange }\end{array}$ & $\begin{array}{l}\text { Lend money to foster appropriate investment growth and development of the } \\
\text { industry. } \\
\text { Act as an intermediary or a broker to facilitate the process of buying and } \\
\text { selling. }\end{array}$ \\
\hline $\begin{array}{l}\text { International } \\
\text { organisations }\end{array}$ & $\begin{array}{l}\text { International Maritime } \\
\text { Organisation }\end{array}$ & Ensure and influence the maritime industry to take on board best practices \\
\hline Media & $\begin{array}{l}\text { Press } \\
\text { Online media } \\
\text { Social media } \\
\text { Television and Radio media }\end{array}$ & Make available publicly information with respect to the industry \\
\hline
\end{tabular}

and concerns could have a significant influence on the organisation's sustainable practices (Sharma and Henriques, 2005). This is consistent with Ayuso et al. (2011) conclusion that fostering engagement with different stakeholders is a valid mechanism for promoting sustainable development within firms. While stakeholder engagement proves to be mutually beneficial in pursuing the shared goals among various stakeholders, continuous dialogue with the firm stakeholders remain a crucial part of sustainability reporting and development.

\section{DEVELOPING A SUSTAINABILITY STAKEHOLDERS ENGAGEMENT FRAMEWORK}

\section{Theoretical Framework}

Stakeholder theory is considered useful when seeking to describe the business environment. A stakeholder has been defined as "any group or individual who can be affected or is affected by the achievement of the organisation's objectives" (Freeman, 1984: 46). Savage et al. (1991: 61) defined stakeholders as groups or individuals who "have an interest in the actions of an organisation and ... the ability to influence it”. Likewise, the Project Management Institute (PMI) Standards Committee (2004) referred to a stakeholder as individuals, group of individuals and organisations who are actively involved in a project or whose interests may be affected by the implementation/execution of a project. These definitions are consistent with Foley (2005: 138) assertion that stakeholders are "those entities and/or issues, which a business identifies from the universe of all who are interested in and/or affected by the activities or existence of that business, and are capable of causing the enterprise to fail, or could cause unacceptable levels of damage if their needs are not met". These views suggest the need for interdependence between an organisation and its stakeholders. Hence, it becomes imperative to seek stakeholders support through adequate and appropriate engagement. 
Gao and Zhang (2006) defined stakeholder engagement as a process that involves an organisation sharing views through genuine dialogue with its shareholders. Involving organisation stakeholders in decision making through information sharing, dialoguing and establishing an avenue for mutual responsibility is an essential aspect of stakeholder engagement. This is consistent with Andriof and Waddock (2002: 9) definition of stakeholder engagement as a process that "creates a dynamic context of interaction, mutual respect, dialogue and change, not a unilateral management of stakeholders". Arguably, stakeholder engagement involves attempts made by an organisation to involve its stakeholders in the organisation's activities. In the same manner, Greenwood (2007) defined stakeholder engagement as practices undertaken by an organisation to involve stakeholders in its activities and/or operations. Reed (2008) added that stakeholder engagement entails a process where individuals, groups and organisations choose to take an active role in making decisions that affect them. This definition emphasises the essence of participation of those who are affected by or can affect a decision. The International Standard Organisation (ISO) (2010: 4) referred to stakeholder engagement as all the activities carried out by an organisation to "create opportunities for dialogue between an organisation and one or more of its stakeholders with the aim of providing an informed basis for the organisation's decisions". These views further suggest that establishing, developing and maintaining relationships with stakeholders is imperative while engaging stakeholders.

Scholars such as Lawrence (2002) argued that successful stakeholder engagement would result in value creation resulting from dialogue and motivation among the parties concerned. Other scholars and researchers have argued and concluded that successful stakeholder engagement could be a source of reputation gains, facilitate commitment and promoting cooperation amongst stakeholders and corporations, foster project success and stakeholder satisfaction, promote ethically sound decision-making and balanced diverse claims, encourage trust and legitimacy to operate in a given environment, and foster economic benefits (Cennamo et al., 2009; Gao and Zhang, 2006). However, Reed (2008) argued that the quality of decisions made through stakeholder participation is firmly dependant on the nature of the process leading to such decisions. This is consistent with Holmes (2011) assertion that stakeholder engagement involves different ongoing activities and/or processes that build trust and relationship. Building on these arguments, this study will, therefore, adopt Reed's series of eight practices for conducting successful stakeholder engagement as listed below:

1. Stakeholder participation needs to be underpinned by a philosophy that emphasises empowerment, equity, trust and learning.

2. Where relevant, stakeholder participation should be considered as early as possible and throughout the process.

3. Relevant stakeholders need to be analysed and represented systematically.

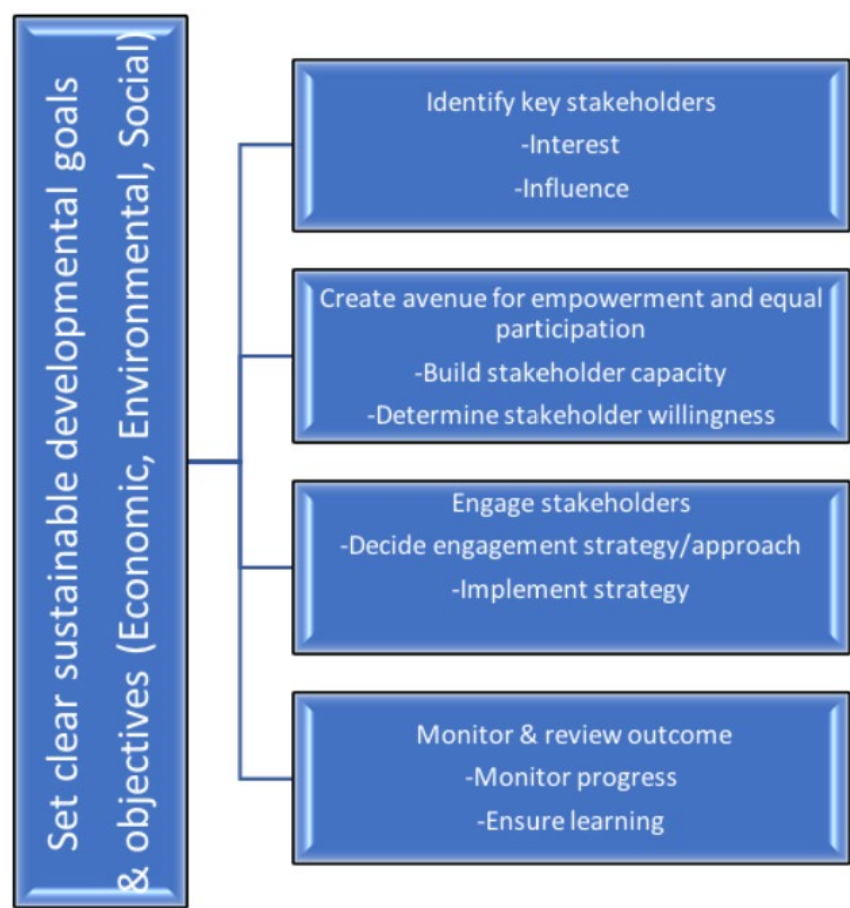

Figure 2. A proposed iterative five-stage framework for engaging stakeholders to fostering sustainable development in a maritime cluster

4. Clear objectives for the participatory process need to be agreed among stakeholders at the outset.

5. Methods should be selected and tailored to the decision-making context, considering the objectives, type of participants and appropriate level of engagement.

6. Highly skilled facilitation is essential.

7. Local and scientific knowledge should be integrated.

8. Participation needs to be institutionalised.

The author concluded that the dynamic and complex nature of environmental problems requires a transparent and flexible decision-making process, which will embrace diversity in values and knowledge. One could, therefore, conclude that stakeholder engagement is instrumental to participation, fostering equality, promoting inclusive decision making and building social capital, which is imperative to explain sustainable development.

\section{Engagement Criteria for Sustainable Engagement}

In this section, we adopt Reed's (2008) eight key features of best stakeholder engagement practice, which provides an extensive evaluation of stakeholder engagement as a concept, to develop a conceptual framework to correctly identify and engage the key stakeholders within a maritime cluster. Reed argued in support of genuine involvement of all stakeholders by providing a guide to effectively and efficiently engage stakeholders.

Figure 2 presents a five-stage stakeholder engagement framework, which is examined in detail below:

Setting clear sustainable developmental goals and objectives: Reed (2008) argued that engagement process must have clear objectives from the outset. Organisations must 


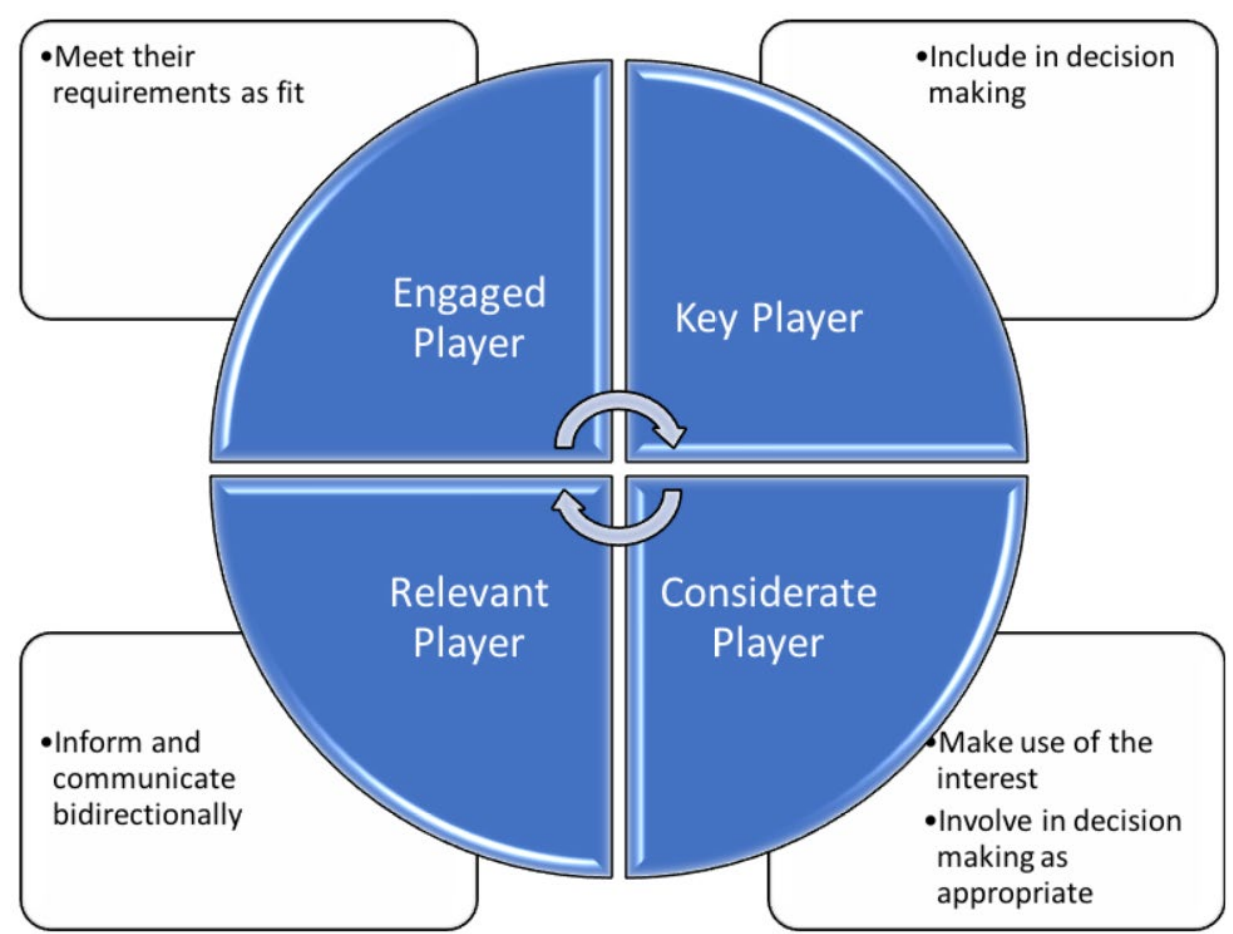

Figure 3. A proposed iterative decision matrix for stakeholder identification

identify and establish clear goals towards which the clusters will be working. In line with this view, Gopnik et al. (2012) asserted that it is important to state clearly the objectives of any engagement process. Hence, the absence of clearly articulated objectives could result in poor implementation of the other stages within the proposed engagement framework. The setting of clear sustainable developmental goal within the proposed framework as presented in Figure 2 has a relationship with the remaining four stages of the framework. It represents a success factor and a guide for the subsequent steps while implementing the engagement process. Talley et al. (2016) added that setting clearly articulated goal suggests that consideration is being given to the likely outcomes of the engagement process. Hence, clusters can plan about the subsequent stages within the engagement process. Arguably, setting clear goals and objectives from the onset of a stakeholder engagement process is imperative because it will help identify stakeholders that could influence (i.e. positive or negative) such objectives.

Identifying key stakeholders: This stage focuses on identifying who to engage based on the identified goals and objectives. It involves analysing the interest and influence of stakeholders to determine who to include or exclude. It is likely impossible for an organisation to have all stakeholders on board during the identification stage. Hence, the need to set clear goals and objectives from the onset of the engagement process. The process of identifying the key stakeholders is an iterative process in which stakeholders are included or removed to ensure that all relevant stakeholders are represented at every stage within the engagement process. Mitchell et al. (1997) stated that any stakeholder possessing one or more of the three relationship attributes: power, legitimacy and urgency should be considered relevant. It becomes crucial to identify and include all the relevant stakeholders as this will improve both the efficiency and effectiveness of the engagement process and intended outcomes. Osobajo and Moore (2017) added that identifying and having appropriate knowledge of the key stakeholders concerning their intentions, interests, behaviour, influences, and interrelations are essential for successful engagement.

This is an essential step for maritime-related clusters, as to our experience, several related organisations are highly interest but less influential, and on the contrary, some organisations are not engaged but highly significant. As a result, Nordstrom et al. (2016) stated that establishing a broad stakeholder network is instrumental in providing developmental feedbacks and inputs. To better understand this difference, we are suggesting the following involvement decision matrix for the maritime industry, as shown in Figure 3.

Create an avenue for empowerment and equal participation: After identifying the relevant stakeholders, it is imperative to establish or create an opportunity for empowerment and equal participation for all identified stakeholders. Empowering stakeholders involves ensuring that relevant identified stakeholders can engage and the ability to influence the decision-making process. Weber and Christopherson (2002) argued that for engagement to be effective, stakeholders must be provided with the opportunity and ability to participate in decision-making. Likewise, identified stakeholders must be availed the chance of getting involved on a level playing field (Reed, 2008). These are conditions that are considered essential to successful stakeholder engagement and effective decisions making. Viederyte (2013: 629) concluded that "to optimise efficiency, to increase the level of business formations and to reach a higher level of innovation", all stakeholders must be included in the organisational structure. Hence, organisations need to foster a reasonable and fair decision-making process that empowers and create an opportunity for equal participation 
Table 2. Profiles of the interviewees

\begin{tabular}{|c|c|c|c|c|c|c|}
\hline Interviewee & Entity & Role & Organization Level & $\begin{array}{c}\text { Years of } \\
\text { Experience }\end{array}$ & Qualification & $\begin{array}{c}\text { No. of } \\
\text { Interviews }\end{array}$ \\
\hline$\# 1$ & $\begin{array}{c}\text { Third Party Logistics } \\
\text { (3PL) }\end{array}$ & $\begin{array}{l}\text { Commercial } \\
\text { Manager }\end{array}$ & $\begin{array}{c}\text { Management } \\
\text { (SME) }\end{array}$ & 25 & Degree in Business & 2 \\
\hline$\# 2$ & $\begin{array}{l}\text { Port / Terminal } \\
\text { Facility }\end{array}$ & Security Officer & $\begin{array}{l}\text { Board Level (Large } \\
\text { Company) }\end{array}$ & 25 & Graduate Degree & 2 \\
\hline$\# 3$ & $\begin{array}{c}\text { Research } \\
\text { Organisation }\end{array}$ & $\begin{array}{c}\text { Senior } \\
\text { Researcher }\end{array}$ & $\begin{array}{l}\text { Operational (Public } \\
\text { Organisation) }\end{array}$ & 7 & $\mathrm{PhD}$ & 2 \\
\hline
\end{tabular}

among stakeholders. Also, encouraging learning between stakeholders who are perceived to have very different perspectives and knowledge.

Engage stakeholders: Engaging the relevant identified stakeholders is in line with Reed's deduction that there is a need to put in place appropriate methods for engaging each stakeholder identified. Reed (2008: 2424) asserted that "methods should be selected and tailored to the decisionmaking context, considering the objectives, type of participants and appropriate level of engagement”. It is, therefore, essential to take into consideration the identified sustainable development goals and objectives in the process of engaging stakeholders. Hence, there is a link between setting clear sustainable developmental goals and objectives and engaging stakeholders. Also, it suggests that identified stakeholders could be subjected to different modes of engagement as there are various methods for engaging stakeholders. In essence, an appropriate engagement model should be defined or determined for each stakeholder identified. For example, modes of engagement, such as focus groups and public meetings, may not be suitable for stakeholders who are not educated because it may involve reading and writing. Likewise, it may become necessary to involve the service of a translator where there are stakeholders whose first language is not English. These examples further support the need to select and tailor methods to suit different stakeholder's need during the engagement process. Whilst it is crucial to involve and engage all maritime stakeholders to jointly improve awareness and identify which threats exist within the industry, Allen et al. (2013) asserted that modes of engagement should take into consideration stakeholders' context such as environmental and socio-cultural factors by accounting for any inherent complexity and likely obstacles that could impact their level of engagement. Hence, Nordstrom et al. (2016) concluded that appropriately engaging various stakeholders will result in a shared understanding of the expected outcome.

Monitor and review outcome: It is imperative to undertake regular monitoring and review of the engagement process. Organisations must carry out up to date comparison of the actual engagement outcomes against the set goals and objectives. Hence, adjustments can be made to what is not working well. In line with this view, Keen and Mahanty (2006) asserted that monitoring and review could provide feedbacks that can influence ongoing and future efforts. Arguably, one could conclude that this stage provides an opportunity for stakeholders' performance measurement and lessons learnt to encourage continual improvement in terms of sustainable development. It requires that all identified stakeholders' performance be measured against set goals and objectives to decide how they are contributing to sustainable development. Monitoring and review are an essential part of the process to measure performance, identify opportunities and improve quality and efficiency of performance for progressive improvements.

\section{Initial Validation}

Because there is limited previous research on practical frameworks of sustainably engaging stakeholders in maritime clusters, we followed an exploratory research approach (Edmonson and McManus, 2007). Our study observed a twostage process (Bryman and Bell, 2015), with Stage 1 being a contextual longitudinal literature review which sets the framework (presented previously) and identifies key relationships of the eco-system. Stage 2 involved the validation of the proposed framework. Stage 2, a fieldresearched validation case study, is based on semi-structured questionnaires (Galletta and Cross, 2013) that facilitated the collection of primary data. The reason for selecting this method is due to the subject's novelty and limitations. The cooperation with people and organisations, helped authors establish a rapport that enabled a more thorough understanding of the processes. The first round of interviews was executed in June 2019 and validated the baseline understanding of the attributes identified above. A follow-up interview on July 2019 clarified intrinsic components of the proposed framework and enabled greater consistency between the two interview rounds.

Each interview had a duration between 1 to 2 hours with the same semi-structured questions being presented to interviewees. Table 2 describes the profile of the interviewees, who were identified based on the authors' network. In analysing the data, we followed Eisenhardt's (1989) case study approach as the interview data were used for a focused thematic analysis.

More specifically, the first interview was used to gain feedback for the proposed framework, and thematic analysis was conducted to analyse the insights gained and establish the main thematic categories, for example, key stakeholders, activities and collaboration patterns. The second round of the interviews clarified elements of the conceptual framework and improved the consistency among the interviewees' responses and the authors understanding.

\section{Case Study: Engaging Stakeholders from the Piraeus Cluster for Sustainable Development}

The interviews were based on a hypothetical scenario presented to the interviewees, which included the implementation of major infrastructural work. It was made clear to the interviewees that by "Infrastructural Works" the 
authors defined projects that include significant disruption to the local community, that are capital intensive and that had significant growth potential for their companies.

The interviewees were asked to use the five-stage framework and to apply this to their contextual case. All interviewees agreed that setting early sustainable developmental goals will help their companies not only define the plans but also communicate these plans to their local stakeholders. This is consistent with Reed (2008) and Gopnik et al. (2012) argument that setting clearly articulated sustainable developmental goals and objectives will aid the successful implementation of the engagement subsequent stages. The increased demand for sustainable development is a leading trait of modern communities, and as such, these objectives were considered to be easier to be communicated within the local communities. Nevertheless, the most crucial feedback collected was the capacity to identify correctly those stakeholders that need further engagement. All interviewees suggested that correctly identifying the right stakeholders and engaging them at the right time, is of paramount importance to the success of any project. This aligns with Osobajo and Moore (2017) assertion that identifying and having appropriate knowledge of the key stakeholders with respect to their intentions, interests, behaviour, influences and interrelations is essential for successful engagement. Likewise, Mitchell et al. (1997) observed that considering relevant stakeholders based on one or more of the three relationship attributes of power, legitimacy and urgency will improve both the efficiency and effectiveness of the engagement process and intended outcomes. The proposed tool is perceived to be robust in terms of recognising these stakeholders and addressing their power in a form that can help effectively steer the projects. All interviewees agreed that each company has its approach and framework to approach stakeholders, which may well be adapted to follow more closely the proposed five-step model. Finally, the interviewees confirmed that in engaging local stakeholders they don't actively monitor the outputs and more importantly the outcomes of the meetings, which was considered by all interviewees as an essential demotivator that challenges implementation plans. According to Keen and Mahanty (2006), in the absence of appropriate monitoring and review process, organisations will often miss out from receiving useful feedbacks that can influence ongoing and future efforts toward promoting sustainable development in the maritime industry. Furthermore, in all organisations, there is no formal "lessons learned" process that feeds back to the central planning processes, and this hinders the co-creation opportunities as well as affects the efficiency of the sustainable engagement of the stakeholders.

\section{CONTRIBUTION TO KNOWLEDGE}

Ongoing discussions and research studies on promoting sustainable development within the maritime industry has increased rapidly in the last two decades. Despite the discussions and research studied conducted, stakeholder engagement as a concept, including its practical implementation, in terms of delivering sustainable development is still relatively unexplored (Dinwoodie et al.,
2012; Videira et al., 2012). Research studies have been carried out on broad aspects of maritime stakeholder analysis, stakeholder participation in management decision-making, the role of stakeholders in the Maritime planning process, and very little research studies have been carried out on engaging stakeholders in maritime operations and activities. Hence this paper contributes to the theoretical knowledge by developing a conceptual framework to correctly identify and engage the key stakeholders within a maritime cluster to promote sustainable development (Figure 1). Also, the tools presented are aimed at both political and business decision-makers with the intention to support them identify, select and include the correct maritime stakeholders in support of the cluster's objectives.

\section{CONCLUSION}

Drawing from the literature, it is evident that there is a need to identify and include different stakeholders operating within the industrial and/or professional clusters. The omission of these stakeholders from the decision-making processes may fail to address sustainability issues in the ongoing discussions and research studies on promoting sustainability within the maritime industry. From a business perspective, this article has presented a conceptual framework to engage stakeholders in the industrial and/or professional clusters that incorporate elements of stakeholder management theory. The framework presented here (for engaging stakeholders) demonstrates that industrial and/or professional clusters have different business responsibilities to fulfil within their operating environment. These business responsibilities are influenced by the existence of other actors, known as stakeholders. Hence, an awareness of these stakeholders will foster the achievement of maritime sustainable developmental goals and objectives.

It is essential to emphasise the need to successfully identify all relevant stakeholders within the industrial and/or professional clusters. This is because various stakeholders have different needs and expectations. Also, fostering effective communication among the identified stakeholders to ensures that they receive information that is relevant to their needs and builds positive attitudes to the organisation's sustainable development projects is important. Frequent monitoring and review of performance, which is considered either missing or inadequate is imperative. Measuring the performance of all identified stakeholders after engaging them is vital to the whole process because it allows progressive improvements. This will further create an avenue for organisations to create a knowledge centre through lessons learnt from the monitoring and review process. In summary, engaging stakeholders implies that industrial and/or professional clusters should aim to identify and engage relevant stakeholders to address sustainable development goals and objectives, which will ultimately contribute to the global effort in combating climate change and its impacts.

It is worth stating that this paper reports the findings of a conceptual research study, and the next step will be to collect data from a larger sample of professionals within the maritime industry. This will permit for a future research study focused 
on validating the process for project stakeholder engagement within the maritime industry. It would also be useful to explore the different modes of engagement that can be taken on board during the engaging stakeholder stage towards the achievement of the set sustainable development goals and objectives.

\section{REFERENCES}

Allen, E., Kruger, C., Leung, F. Y. and Stephens, J. C. (2013). Diverse perceptions of stakeholder engagement within an environmental modeling research team. Journal of Environmental Studies and Sciences, 3(3), 343-356. https://doi.org/10.1007/s13412-013-0136-X

Amaeshi, K. M. and Crane, A. (2006). Stakeholder engagement: a mechanism for sustainable aviation. Corporate social responsibility and environmental management, 13(5), 245260. https://doi.org/10.1002/csr.108

Andriof, J. and Waddock, S. (2002). Unfolding stakeholder engagement. In J. Andriof, S. Waddock, B. Husted and S. Rahman (eds), Unfolding Stakeholder Thinking: Theory, Responsibility and Engagement (pp. 19-42). Greenleag Publishing: Sheffield.

Arslan, V., Kurt, R. E., Turan, O. and De Wolff, L. (2016). Safety culture assessment and implementation framework to enhance maritime safety. Transportation research procedia, 14, 3895-3904. https://doi.org/10.1016/j.trpro.2016.05.477

Ayuso, S., Ángel Rodríguez, M., García-Castro, R. and Ángel Ariño, M. (2011). Does stakeholder engagement promote sustainable innovation orientation? Industrial Management and Data Systems, 111(9), 1399-1417. https://doi.org/ 10.1108/02635571111182764

Benito, G. R., Berger, E., De la Forest, M. and Shum, J. (2003). A cluster analysis of the maritime sector in Norway. International Journal of Transport Management, 1(4), 203215. https://doi.org/10.1016/j.ijtm.2003.12.001

Bryman, A. and Bell, E. (2015). Business Research Methods (4th Ed.), Oxford: Oxford University Press.

Cennamo, C., Berrone, P. and Gomez-Mejia, L. (2009). Does stakeholder management have a dark side? Journal of Business Ethics, 89, 491-507. https://doi.org/10.1007/ s10551-008-0012-X

Chen, S. L., Jeevan, J. and Cahoon, S. (2016). Malaysian container seaport-hinterland connectivity: Status, challenges and strategies. The Asian Journal of Shipping and Logistics, 32(3), 127-138. https://doi.org/10.1016/j.ajsl. 2016.09.001

Denktas-Sakar, G. and Karatas-Cetin, C. (2012). Port sustainability and stakeholder management in supply chains: A framework on resource dependence theory. The Asian Journal of Shipping and Logistics, 28(3), 301-319. https://doi.org/10.1016/j.ajsl.2013.01.002

Dinwoodie, J., Tuck, S., Knowles, H., Benhin, J. and Sansom, M. (2012). Sustainable development of maritime operations in ports. Business Strategy and the Environment, 21(2), 111126. https://doi.org/10.1002/bse.718
Doloreux, D. and Shearmur, R. (2009). Maritime clusters in diverse regional contexts: The case of Canada. Marine Policy, 33(3), 520-527. https://doi.org/10.1016/j.marpol. 2008.12.001

Doloreux, D., and Melançon, Y. (2008). On the dynamics of innovation in Quebec's coastal maritime industry. Technovation, 28(4), 231-243. https://doi.org/10.1016/ j.technovation.2007.10.006

Edmonson, A. and McManus, S. (2007). Methodological fit in management field research. Academy of Management Review, 32(4), 1155-1179. https://doi.org/10.5465/ amr.2007.26586086

Eisenhardt, K. M. (1989). Building Theories from Case Study Research. Academy of Management Review, 14(4), 532-550. https://doi.org/10.5465/amr.1989.4308385

Engel, J.R. (1990). Introduction: The ethics of sustainable development. Ethics of environment and development: Global challenge, international response, 1-23.

Foley, K. (2005). Meta-management: a stakeholder/quality management approach to wholeof-enterprise management. SAI Global. Sydney.

Freeman, R. E. (1984). Strategic Management: A Stakeholder Approach (1st Ed.). Pitman Publishing: Boston, MA, USA, 24-25.

Galletta, A. and Cross, W. (2013). Mastering the Semi-Structured Interview and Beyond: From Research Design to Analysis and Publication. NYU Press, 2013

Gao, S. S. and Zhang, J. J. (2006). Stakeholder engagement, social auditing and corporate sustainability. Business process management journal, 12(6), 722-740. https://doi.org/10.1108/14637150610710891

Gladwin, T. N., Kennelly, J. J. and Krause, T. S. (1995). Shifting paradigms for sustainable development: Implications for management theory and research. Academy of management Review, 20(4), 874-907. https://doi.org/10.5465/amr.1995. 9512280024

Gopnik, M., Fieseler, C., Cantral, L., McClellan, K., Pendleton, L. and Crowder, L. (2012). Coming to the table: Early stakeholder engagement in marine spatial planning. Marine Policy, 36(5), 1139-1149. https://doi.org/10.1016/ j.marpol.2012.02.012

Greenwood, M. (2007). Stakeholder engagement: beyond the myth of corporate responsibility. Journal of Business Ethics, 74, 315-327. https://doi.org/10.1007/s10551-007-9509-y

Holmes, B. (2011). Citizens' engagement in policymaking and the design of public services. Canberra: Parliamentary Library.

International Maritime Organisation (IMO) (2020). IMO and the Sustainable Development Goals. Online. Available at: http://www.imo.org/en/MediaCentre/HotTopics/Pages/Su stainableDevelopmentGoals.aspx (Accessed: 11 September 2020).

International Standard Organisation (ISO) (2010). Guidance on social responsibility. International Standard ISO/DIS 26000. Geneva: International Organisation for Standardisation. 
Johnson, H., Johansson, M., Andersson, K. and Sodahl, B. (2013). Will the ship energy efficiency management plan reduce $\mathrm{CO} 2$ emissions? A comparison with ISO 5001 and the IMS code. Maritime Policy and Management, 40(2), 177190. 90. https://doi.org/10.1080/03088839.2012.757373

Kacmaz, E., Kara, G. and Yıldız, M. (2016). Evaluation of marine pollution caused by tanker ships and preventing under focus of the international regulations. Proceedings book, 318.

Keen, M. and Mahanty, S. (2006). Learning in sustainable natural resource management: challenges and opportunities in the Pacific. Society and Natural Resources, 19(6), 497-513. https://doi.org/10.1080/0894192060066 3896

Koliousis, I. G., Papadimitriou, S., Riza, E., Stavroulakis, P. J. and Tsioumas, V. (2018). Scarcity theory and maritime clusters: From paradox to modelling. Marine Policy, 93, 4046. https://doi.org/10.1016/j.marpol.2018.03.029

Kwak, S. J., Yoo, S. H. and Chang, J. I. (2005). The role of the maritime industry in the Korean national economy: an input-output analysis. Marine Policy, 29(4), 371-383. https://doi.org/10.1016/j.marpol.2004.06.004

Langen, P. D. (2002). Clustering and performance: the case of maritime clustering in The Netherlands. Maritime Policy \& Management, 29(3), 209-221. https://doi.org/10.1080/030 8883021013260

Lawrence, A. T. (2002). The drivers of stakeholder engagement: Reflections on the case of Royal Dutch/Shell. The Journal of Corporate Citizenship, 71-86.

Lee, C. and Lam, J. (2012). Managing reverse logistics to enhance sustainability of industrial marketing. Industrial Marketing Management, 589-598. https://doi.org/10.1016/ j.indmarman.2012.04.006

Maguire, B., Potts, J. and Fletcher, S. (2012). The role of stakeholders in the marine planning process- Stakeholder analysis within the Solent, United Kingdom. Marine Policy, 36, 246-257. https://doi.org/10.1016/j.marpol.2011.05.012

Mitchell, R. K., Agle, B. R. and Wood, D. J. (1997). Toward a theory of stakeholder identification and salience: Defining the principle of who and what really counts. Academy of management review, 22(4), 853-886. https://doi.org/ 10.5465/amr.1997.9711022105

Nordström, J., Goerlandt, F., Sarsama, J., Leppänen, P., Nissilä, M., Ruponen, P., Lübcke, T. and Sonninen, S. (2016). Vessel TRIAGE: A method for assessing and communicating the safety status of vessels in maritime distress situations. Safety science, 85, 117-129. https://doi.org/10.1016/ j.ssci.2016.01.003

Osobajo, O. A. and Moore, D. (2017). Who is Who? Identifying the Different Sub-groups of Secondary Stakeholders within a Community: A Case Study of the Niger Delta Region of Nigeria Communities. International Business Research, 10(9), 188-209. https://doi.org/10.5539/ibr.v10n9p188
Pagano, A., Wang, G., Sánchez, O., Ungo, R. and Tapiero, E. (2016). The impact of the Panama Canal expansion on Panama's maritime cluster. Maritime Policy \& Management, 43(2), 164-178. https://doi.org/10.1080/03088839.2016. 1140241

Pinto, H., Cruz, A. R. and Combe, C. (2015). Cooperation and the emergence of maritime clusters in the Atlantic: Analysis and implications of innovation and human capital for blue growth. Marine Policy, 57, 167-177. https://doi.org/10.1016/j.marpol.2015.03.029

Potter, B. (2017). Environmental policy in California: setting the stage for marine invasive species management.

Project Management Institute Standards Committee. (2004). A Guide to the Project Management Body of Knowledge (3rd Ed.). Pennsylvania, PA, USA, 2004; 81-86.

Reed, M. S. (2008). Stakeholder participation for environmental management: a literature review. Biological conservation, 141(10), 2417-2431. https://doi.org/10.1016/ j.biocon.2008.07.014

Rotheroe, N., Keenlyside, K. and Coates, L. (2003). Local agenda 21: articulating the meaning of sustainable development at the level of the individual enterprise. Journal of Cleaner Production, 11, 537-548. https://doi.org/10.1016/S0959-6526(02)00075-6

Savage, G. T., Nix, T. W., Whitehead, C. J. and Blair, J. D. (1991). Strategies for assessing and managing organisational stakeholders. Academy of Management Executive, 5(2), 6175. https://doi.org/10.5465/ame.1991.4274682

Sharma, S. and Henriques, I. (2005). Stakeholder influences on sustainability practices in the Canadian forest products industry. Strategic management journal, 26(2), 159-180. https://doi.org/625 10.1002/smj.439

Svensson, E. (2012). Sustainable shipping in the European Union. Available at: http://www.chalmers.se/gmv/EN/projects/ epsd/downloadFile/attachedFile_f0/Sustainable_Shipping in_the_European_Union?nocache $=1361441035.61$ (Accessed: 5 January 2019).

Talley, J. L., Schneider, J. and Lindquist, E. (2016). A simplified approach to stakeholder engagement in natural resource management: The Five-Feature Framework. Ecology and Society, 21(4). https://doi.org/10.5751/ES-08830-210438

Viederyte, R. (2013). Maritime cluster organizations: Enhancing role of maritime industry development. Procedia-Social and Behavioral Sciences, 81, 624-631. https://doi.org/10.1016/j.sbspro.2013.06.487

Weber, N. and Christophersen, T., 2002. The influence of nongovernmental organisations on the creation of Natura 2000 during the European Policy process. Forest policy and economics, 4(1), 1-12. https://doi.org/10.1016/S13899341(01)00070-3 